\section{Conservation goes commercial}

\section{Provincetown, Massachusetts}

THE commercial exploitation of whales is once again a modest success in this small town, until a century or so ago one of the score of New England ports with a fleet of whalers on its books. But now the objective is not killing whales but watching them. At least four small enterprises operate diesel launches that offer visitors a chance to see a whale for between $\$ 10$ and $\$ 13$ a head. Business thrives, at least on clear days. The whales are not physically harmed, but what they think of the small flotilla scouring the nearby banks for a sight of them is not recorded.

The growth of this modest industry in the past eight years is not just a proof that conservation policy need not be an unmitigated drain on the public purse but also a neat demonstration of a symbiotic relationship between a commercial enterprise and an informal research enterprise - the Cetacean Research Program, based at Provincetown. The boat-owners give the whale-watchers access to their animals, not only off Cape Cod but, out of season, in the Caribbean. The conservationists repay this kindness by providing an intelligent running commentary on the proceedings.

Charles Mayo, the guide on one of the Dolphin Company's boats last week, and one of the founders of the Cetacean $\mathrm{Re}$ search Program, has obviously learned in seven seasons to forestall the frustration of a hundred or so people who see nothing after four hours at sea. He emphasized from the start that on such a hazy morning, the chances of seeing a whale were bound to be small, especially because the upwelling of cold water off the submarine glacial morains where the whales feed might turn the haze into fog. Obligingly for the peace of mind of a hundred or so passengers, a fin-whale appeared right on cue, displaying its dorsal fin as if it were an oversized dolphin gambolling half a dozen times between five-minute dives. angliae), although on the average only 40 feet in these parts, are easier to see, at least on summer mornings, because of their habit of lying on the surface. They are also identifiable (to an enthusiast with a long telephoto lens on his camera) by the shapes of the white patches on their bellies and the flecks of white on their dorsal fins and tails. The Cetaceans have given them names one of three lying half asleep on the surface was excitedly recognized as "Little Spot", a calf known to have been born early in 1979 in the waters around the Antilles. The other two, a mature female and a first season calf, declined to display enough of their tails for instant identification.

The Cetacean Research Program now reckons to have distinguished 230 humpback whales in the waters off the western edge of the Stellwagen Bank, many of
Humpback whales (Megaptera novae- which have been also recognized at the southern extreme of their migration to the Caribbean (where they mate). Mayo is working on a detailed account of 213 of them for publication and says that the data he and his associates have gathered are the "best database on humpbacks in the world".

So are they still in danger of extinction? Mayo cannot be sure, but thinks the scanty evidence may be encouraging. The number of first-season calves recognized in the water increased from 4 in 1979 to 12 in 1983 , while this year they have found a further 12 with three months yet to go before the annual migration south. Surprisingly, while calves return with their mothers in the second season, at two-plus (when suckling is over) two thirds have transferred allegiance to another female. As yet, there is nothing like a comprehensive survey of the humpback population off this northeast coast, while both fin and humpback whales from the Greenland populations may still be hunted legally.

The Cetacean Research Program is run on a shoestring, raising $\$ 160,000$ last year from the US branch of the World Wildlife Fund, a number of small foundations and by the sale of buttons on the boats for a taxdeductible $\$ 2$. Most of the money goes on film and equipment, with a tiny subsistence for those working far from home. The project would prefer not to have to ask the Dolphin Company for a commission for fear of compromising its independence.

There is also a petition to sign asking for a total ban on hunting and for the protection of critical whale habitats; signatories line up in the inner cabin with studied nonchalance as if they were coming forward at a Billy Graham meeting. The hope is to better last year's roster of 45,000 signatures, which were "sent straight off to the [international] whaling commission".

This is the only hard-sell on behalf of conservation on the voyage, although it is occasionally let slip that this or that animal may have been killed before being able to return next year.

Much will no doubt depend on whether the whales regularly perform as well as they did last week. One fin whale first sighted straight ahead rushed by the Dolphin vessel at a distance of about 5 metres in an imitation of an animated nuclear submarine. Three minke whales (Balaenoptera acutorostrata) moved rapidly through the fog and long before half a dozen fin whales had been seen close to, some whale-watchers were hardened enough to keep their noses firmly in their books. Little Spot and her two companions were found on the return journey in almost exactly the same place, still half-asleep. One other humpback female some miles away, at first thought to have been Little Spot's mother (called Columbia), after imitating a 50-foot crocodile and a leaping dolphin, spread her tail above the water for long enough to have Mayo rushing about shouting "That's Ivory!" just as a man might recognize an old flame in the middle of nowhere. Ivory, he says, has been back with four calves since 1977, and now they hope she is pregnant again. If it goes on like this, the whales will be bumping into each other. Two of the Dolphin company's boats plying staggered shifts seemed to have some difficulty in avoiding a collision last week.

John Maddox

\section{Nature index of biotechnology stocks}

\begin{tabular}{|c|c|c|c|c|c|}
\hline $\begin{array}{l}\text { 12-Month } \\
\text { high }\end{array}$ & $\begin{array}{l}\text { 12-Month } \\
\text { low }\end{array}$ & Company & $\begin{array}{l}\text { Close } \\
\text { previous } \\
\text { month }\end{array}$ & $\begin{array}{l}\text { Close } \\
27 \text { July }\end{array}$ & Change \\
\hline 14 & 6 & Biogen (Switzerland) & $81 / 2$ & $63 / 4$ & $-13 / 4$ \\
\hline 2 & 1 & Bio-Logicals (Canada) & $15 / 8$ & $1 \frac{1}{8}$ & $-1 / 2$ \\
\hline $14 \frac{3}{3} / 8$ & $7 \frac{5}{8}$ & Bio-Response (USA) & $83 / 4$ & $81 / 8$ & $-5 / 8$ \\
\hline 14 & $91 / 4$ & Cetus (USA) & $11^{3 / 8}$ & $9^{3 / 8}$ & -2 \\
\hline $10^{3 / 8}$ & $4 \frac{1}{4}$ & Collaborative Research (USA) & $57 / 8$ & $51 / 4$ & $-5 / 8$ \\
\hline $19^{7} / 8$ & $11 \frac{1}{2}$ & Damon (USA) & $141 / 4$ & 13 & $-11 / 4$ \\
\hline $261 / 4$ & $11^{3 / 4}$ & Enzo-Biochem (USA) & 15 & $121 / 2$ & $-21 / 2$ \\
\hline $10 \frac{1}{8}$ & $41 / 4$ & Flow General (USA) & $61 / 2$ & $43 / 4$ & $-13 / 4$ \\
\hline $42 \frac{1}{4}$ & $283 / 4$ & Genentech (USA) & $34 \frac{1}{2}$ & 33 & $-1 \frac{1}{2}$ \\
\hline $103 / 4$ & $41 / 2$ & Genetic Systems (USA) & $53 / 4$ & 5 & $-3 / 4$ \\
\hline $171 / 4$ & $81 / 4$ & Genex (USA) & 9 & $11 \frac{1}{8}$ & $+2 \frac{1}{8}$ \\
\hline 23 & 11 & Hybritech (USA) & 14 & $11 \frac{1}{4}$ & $-31 / 4$ \\
\hline $161 / 4$ & $73 / 4$ & Molecular Genetics (USA) & $101 / 4$ & $83 / 4$ & $-1 \frac{1}{2}$ \\
\hline $151 / 2$ & $81 / 4$ & Monoclonal Antibodies (USA) & 12 & $81 / 4$ & $-33 / 4$ \\
\hline $607 / 8$ & 39 & Novo Industri A/S (Denmark) & $44^{3 / 4}$ & $40^{3 / 8}$ & $-4^{3} / 8$ \\
\hline $223 / 4$ & $14 \frac{1}{2}$ & Pharmacia (Sweden) & $15^{7} / 8$ & $17^{1 / 8}$ & $+11 / 4$ \\
\hline
\end{tabular}

Closing prices are for the last Friday of the month. For over-the-counter stocks, bid price is quoted; for stocks on the American and New York exchanges, the transaction price. Nature's weighted index of biotechnology stocks stood at 138 on $27 \mathrm{July}$, compared with 145 a month earlier. Data from E.F. Hutton, Inc. 